\section{Kognitiv psykoterapi ved psykoser - eneste vei til Rom?}

Chadwick P

Personbasert kognitiv terapi ved psykoser 244 s, tab, ill. Trondheim: Tapir akademisk forlag, 2009. Pris NOK 340

ISBN 978-82-519-2308-8

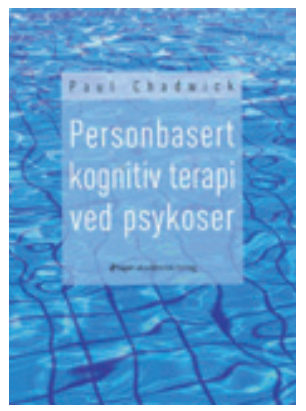

Kognitiv terapi, i utgangspunktet utviklet av Aron Beck til anvendelse ved depresjoner, har stadig fått utvidet indikasjonsområde. Dette har delvis skjedd i modifiserte former, som Marsha Lineans dialek-

tiske atferdsterpi og Jeffrey Youngs skjemafokuserte terapi ved personlighetsforstyrrelser. Når det gjelder psykoser, har effekt av kognitiv terapi vært dokumentert i flere studier, men det er også presentert en noe mer nyansert holdning til bruken av denne terapiformen både i relasjon til pasientens symptomutforming og til samspill med andre terapiformer.

Imidlertid har Paul Chadvick her kun presentert sin modell teoretisk og praktisk, uten motforestillinger eller relatering til andre terapiformer. Han bygger sin personbaserte kognitive terapiform på Carl Rodgers klientsentrerte terapi, som har total aksept av alt klienten kommer med som grunnprinsipp. Via bl.a. sokratisk dialog og tostolsmetoden, der klienten kan lære å differensiere mellom de overveiende negative og de langt mindre fremtredende positive selvvurderinger, skal det etter hvert bli lettere for vedkommende å akseptere sine psykotiske forestillinger.

Forfatteren fremsetter begrepet «nærmeste utviklings-sone» som en viktig teoretisk modell for sitt terapeutiske arbeid med psykotiske pasienter. Den består av symptomatisk mening, forhold til indre opplevelser, arbeid med skjemaer og det symbolske selv. Det innebærer at dersom klienten finner meningen i symptomene, blir seg mer bevisst sine indre opplevelser (ikke minst de psykotiske), oppnår økt erkjennelse av underliggende skjemaer og blir mer fortrolig med et nyansert selvbilde, vil det bidra til økt egenkontroll over atferd og funksjon.

Dette er vel og bra, og det er hevet over tvil at en del psykotiske personer kan ha nytte av en slik terapiform. I septembernummeret 2009 av Schizophrenia Bulletin er det flere artikler der dette temaet behandles fra forskjellige synsvinkler og relatert til varierte terapeutiske tilnærminger. På denne bakgrunn kommer det første store men når det gjelder den foreliggende bok. Psykotiske lidelser spenner over et vidt spekter, med varierende alvorlighetsog tilgjengelighetsgrad. Forfatteren nøyer seg med å hevde at psykose er en del av et kontinuum mot normalitet og gjør så å si ingen forsøk på å differensiere ut fra alvorlighetsgrad ved de kliniske tilstander som presenteres og som i hovedsak dreier seg om å høre stemmer og/eller inneha paranoide forestillinger. Der det angis variasjoner, er det heller eksempler som går i retning av de ikke-psykotiske (s. 88 «... stryke til eksamen ...») enn alvorligere psykotiske tilstander.

Det neste store men er fraværet av refleksjoner over forholdet til andre terapiformer. Eneste gang en annen terapiform nevnes, er i en kasuistikk (s. 219), der det siteres fra en klient: «Jeg har også fått andre typer behandling. En av de aller farligste «behandlingene» jeg har fått, var den medisinske modellen, med alt fra små til enorme doser medisiner og elektrosjokk.»

En så unyansert presentasjon svekker troverdigheten. Publikasjoner fra forskjellige terapiprosjekter ved psykoser er nok til å stadfeste dette. Fra TIPS-prosjektet (Tidlig intervensjon ved psykoser), et multinasjonalt forskningsprosjekt, kommer funn som viser at prognosen for helbredelse av psykoser er korrelert med varigheten av ubehandlet psykose (kortere varighet bedre prognose), med antipsykotisk medikasjon som en vesentlig komponent $\mathrm{i}$ behandlingen.

Personbasert kognitiv terapi ved psykoser, som ikke kan sies å være for nybegynnere i psykoterapifaget, har et interessant om enn for smalsporet budskap. Det vil appellere til spesielt interesserte, uavhengig av om de deler det syn som presenteres $\mathrm{i}$ forordet og som blir det tredje men i denne anmeldelsen: «I psykiatrien har det tidligere vært aksept for en overveiende biologisk forståelse av psykotiske lidelser, noe som har bidratt til en terapeutisk pessimisme når det gjelder effekten av psykoterapi ved psykotiske symptomer.» Dette utsagnet er like unyansert som bruken av det ovenstående sitatet fra en klient. Psykoterapiprosjekter, så vel nasjonale (avdeling Lien, Dikemark sykehus, og Kastanjebakken, Gaustad sykehus) som internasjonale (Barbro Sandins Säter-modell, Chestnut Lodge og Austin Riggs fra USA), overfor unge schizofrene innenfor rammen av en psykodynamisk modell burde være tilstrekkelig dokumentasjon. Videre vil TOPP-prosjektet ved Ullevål universitetssykehus innenfor en kognitiv modell kunne gi ny og interessant kunnskap om feltet. Det vi innenfor det psykiatriske/psykologiske fagfeltet ikke trenger, er holdninger som er med på å hindre et fruktbart s amvirke mellom forskjellige tilnærminger til denne pasientgruppen. En løsning ligger som regel ikke i en "sekterisk» ytterkant, men heller der forskjellige innfallsvinkler kan møtes og flytte kunnskapsfronten fremover innenfor en bio-psyko-sosial forståelsesmodell.

\section{Tore Gude}

Modum Bad

og

Avdeling for atferdsfag

Universitetet i Oslo

\section{Alle trenger et overblikk}

\section{Lillevang ST, Møller BK.} Immunologi

En kortfattet lærebog. 136 s, tab, ill. København: FADL's Forlag, 2009. Pris DKK 350

ISBN 978-87-7749-493-2

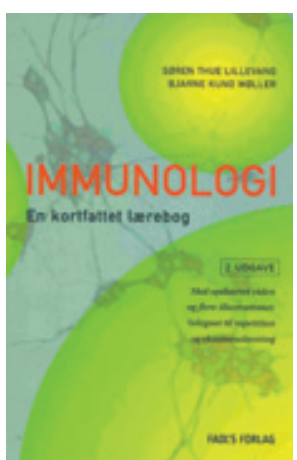

Hvem husker vel ikke ukene før en eller annen eksamen, da læreboken antok dimensjoner av et uoverstigelig kunnskapsberg og lærerens velmente kompendium var like lettlest som Proust? Da ville en konsis, kortfattet lærebok hvor det viktigste var oppsummert ha vært kjærkommen. Ikke som erstatning for den store læreboken - fri og bevare oss - men som et tillegg til de notatene som ikke ble så 